UDC 378.147

\title{
Theoretical and methodological aspects of the organization of supervision for the formation of professional identity of future specialists in physical therapy, ergotherapy
}

\author{
Dmitriieva N.* \\ Akademician Youriy Bugay International Scientific and Technical University, Kyiv, Ukraine
}

Received: $22.10 .2019 \quad$ Accepted: 21.12 .2019

\begin{abstract}
The purpose of the article is to determine the theoretical and methodological aspects of the organization of supervision for the formation of professional identity of future specialists in physical therapy and ergotherapy. The methodological basis for conducting this study was laid by such approaches as theoretical analysis of scientific and methodological literature, synthesis, generalization, comparative analysis. The theoretical analysis of pedagogical, medical, philosophical, psychological and multidisciplinary literature was carried out to solve the purpose of the study. Supervision in research is seen as a formal process of professional support and training that enables practitioners to develop knowledge and competence, to realize responsibility for their own practice. The study found that professional identity in its concept is closely interrelated with such concepts as professional development, professionalism, professional self-esteem, professional self-determination, and is one of the main criteria for becoming a professional in a competitive environment. It is established that the formation of professional identity is the most important task that a professional faces in the period of his professional formation. The technological ways of supporting the supervisor of the effective position of the future specialist in physical therapy and ergotherapy under supervision are highlighted. It is theoretically substantiated that in order to achieve effective supervision for forming the professional identity of future specialists in physical therapy and ergotherapy, a useful role-playing matrix is a useful technology, which allows to analyze in detail the complex cases in the professional activity of physical therapists and ergotherapists. The principle of gradualism is important for the organization of supervision. The article identifies four levels of supervision that are designed for the safe educational practice of specialists in physical therapy and ergotherapy. According to the results of the study, the responsibilities of the supervisor and the future specialist in physical therapy, ergotherapy under supervision, the fulfillment of which is necessary to achieve positive results of supervision, are allocated. Having analyzed the results of the research of the scientific and methodological literature, it is determined that the fulfillment of the allocated responsibilities by the subjects of educational practice will allow the future specialist in physical therapy, ergotherapy to form three main components of professional identity: cognitive, emotional-evaluative, as well as behavioral.
\end{abstract}

Key words: supervision, professional identity, physical therapy, ergotherapy, formation of professional identity, organization of supervision.

\section{Теоретико-методологічні аспекти організації супервізії для формування професійної ідентичності майбутніх фахівців з фрізичної терапії, ерготерапії}

\author{
Дмітрієва Н. С. \\ Міжнародний науково-технічний університет імені академіка Юрія Бугая, Київ, Україна
}

\begin{abstract}
Анотація. Метою статті $є$ визначити теоретико-методологічні аспекти організації супервізії для формування просресійної ідентичності майбутніх фрахівців з фізичної терапії та ерготерапії. Методологічну основу при проведенні даного дослідження заклали такі підходи, як теоретичний аналіз науково-методичної літератури, синтез, узагальнення, порівняльний аналіз. Для вирішення мети дослідження був здійснений теоретичний аналіз педагогічної, медичної, фрілософської, психологічної та мультидисциплінарної літератури. Супервізія у
\end{abstract}

\footnotetext{
Corresponding Author: Dmitriieva Nikol Subkhanivna. Tel. +38(067)765-61-99. E-mail: nikolestern@ukr.net. Akademician Youriy Bugay International Scientific and Technical University, Lane Magnitogorsk, 3, Kyiv, Ukraine, 02000.

Відповідальний автор: Дмітрієва Ніколь Субханівна. Tel. +38(067)765-61-99. E-mail: nikolestern@ukr.net. Міжнародний науково-технічний університет імені академіка Юрія Бугая, провулок Магнітогорський, 3, м. Київ, Україна, 02000.
} 
дослідженні розглядається, як формальний процес професійної підтримки та навчання, який дає можливість практикуючим особам розвивати знання та компетентність, усвідомлювати відповідальність за власну практичну діяльність. За результатами дослідження встановлено, що професійна ідентичність у своєму понятті тісно взаємопов'язана з такими поняттями, як професійний розвиток, професіоналізм, професійна самооцінка, професійне самовизначення, і $є$ одним з основних критеріїв становлення професіонала в умовах конкурентного середовища. Встановлено, що формування професійної ідентичності $€$ найважливішим завданням, яке постає перед фрахівцем у період його професійного становлення. Виділені технологічні способи підтримки супервізором дієвої позиції майбутнього фахівця з фізичної терапії та ерготерапії під супервізією. Теоретично обгрунтовано,що для досягнення ефективної супервізії для формування професійної ідентичності майбутніх фахівців з фізичної терапії та ерготерапії корисною технологією є фокусно-рольова матриця, яка дозволяє детально проаналізувати складні випадки у професійній діяльності фізичних терапевтів та ерготерапевтів. Для організації супервізії важливим $€$ принцип поступовості. У статті виділені чотири рівні супервізії, які розроблені для безпечної навчальної практики фахівців з фрізичної терапії та ерготерапії. За результатами проведеного дослідження виділеніі обов'язки супервізора та майбутнього фахівця з фізичної терапії, ерготерапії, що перебуває під супервізією, виконання яких необхідне для досягнення позитивних результатів супервізії. Здійснивши аналіз отриманих результатів дослідження науковометодичної літератури визначено, що виконання виділених обов'язків суб'єктами навчальної практики дозволить майбутньому фахівцю з фізичної терапії, ерготерапії сформувати три основні компоненти професійної ідентичності: когнітивний, емоційно-оцінний, а також поведінковий.

Ключові слова: супервізія, професійна ідентичність, фрізична терапія, ерготерапія, фрормування професійної ідентичності, організація супервізії.

\title{
Теоретико-методологические аспекты организации супервизии для формирования профессиональной идентичности будущих специалистов по физической терапии, эрготерапии
}

\author{
Дмитриева Н. С. \\ Международный научно-технический университет имени академика Юрия Бгая, Киев, Украина
}

\begin{abstract}
Аннотация. Целью статьи является определить теоретико-методологические аспекты организации супервизии для формирования профессиональной идентичности будущих специалистов по физической терапии и эрготерапии. Методологическую основу при проведении данного исследования заложили такие подходы, как теоретический анализ научно-методической литературы, синтез, обобщение, сравнительный анализ. Для решения цели исследования был осуществлен теоретический анализ педагогической, медицинской, философской, психологической и мультидисциплинарной литературы. Супервизия в исследовании рассматривается как формальный процесс профессиональной поддержки и обучения, который дает возможность практикующим лицам развивать знания и компетентность, осознавать ответственность за свою практическую деятельность. По результатам исследования установлено, что профессиональная идентичность в своем понятии тесно взаимосвязана с такими понятиями, как развитие, профессионализм, профессиональная самооценка, профессиональное самоопределение, и является одним из основных критериев становления профессионала в условиях конкурентной среды. Установлено, что формирование профессиональной идентичности является важнейшей задачей, которая встает перед специалистом в период его профессионального становления. Выделенные технологические способы поддержки супервизором действенной позиции будущего специалиста по физической терапии и эрготерапии под супервизией. Теоретически обосновано, что для достижения эффрективной супервизии для формирования профессиональной идентичности будущих специалистов по физической терапии и эрготерапии полезной технологией является фокусно-ролевая матрица, которая позволяет детально проанализировать сложные случаи в профрессиональной деятельности физических терапевтов и эрготерапевт. Для организации супервизии важен принцип постепенности. В статье выделены четыре уровня супервизии, которые разработаны для безопасной учебной практики специалистов по физической терапии и эрготерапии. По результатам проведенного исследования выдиление обязанности супервизора и будущего специалиста по физической терапии, эрготерапии, что находится под супервизией, выполнение которых необходимо для достижения положительных результатов супервизии. Осуществив анализ полученных результатов исследования научно-методической литературы определено, что выполнение выделенных обязанностей субъектами учебной практики позволит будущему специалисту по физической терапии, эрготерапии сфформировать три основных компонента профессиональной идентичности: когнитивный, эмоциональнооценочный, а также поведенческий.
\end{abstract}

Ключевые слова: супервизия, профессиональная идентичность, физическая терапия, эрготерапия, формирование профессиональной идентичности, организация супервизии. 


\section{Bcmyn}

Сучасна ситуація на ринку праці в Україні, реагуючи на різні перетворення в соціальноекономічному житті країни, реформацію і модернізацію у сфері охорони здоров'я, пред'являє все більш жорсткі вимоги до фахівців з фрізичної терапії та ерготерапії, якості їх професійної діяльності й набору кваліфрікаційних характеристик, вимагаючи конкурентних переваг на ринку праці [2, 4].

Можна стверджувати, що сьогодні перед системою вищої освіти фахівців з фізичної терапії та ерготерапії стоїть завдання - навчити студентів самостійній практиці в галузі фрізичної терапії та ерготерапії, прийняття рішучих дій у професійних ситуаціях, тобто, стимулювати професійне мислення, активізувати творчий потенціал, формувати стійкий інтерес до освіти, майбутньої професії, а також професійну ідентичність. Як один із шляхів вирішення поставлених завдань, зокрема формування професійної ідентичності, пропонується включення супервізії у процес професійної підготовки майбутніх фахівців з фрізичної терапії та ерготерапії $[1,5]$.

Поняття «супервізія» (supervision) перекладається з англійської мови як нагляд, спостереження, керівництво [23]. Використання даного поняття у сфері фрізичної терапії та ерготерапії передбачає, що в ній діє довідчений фахівець (супервізор), який наглядаючи та керуючи діями майбутнього фрахівця 3 фізичної терапії та ерготерапії (або фахівця-початківця) по відношенню до об'єктів фізіотерапевтичних/ерготерапевтичних втручань, і цим надає допомогу у навчальній практичній (професійній) діяльності [20].

Аналіз останніх наукових досліджень і публікацій дозволяє стверджувати, що серед сучасних наукових досліджень з педагогіки вищої школи та психології професійного самовизначення та становлення особистості актуальним $є$ питання підготовки конкурентоспроможних фахівців у вищих навчальних закладах $[15,21]$. Разом із цим результати більшості вказують на те, що для підвищення конкурентоспроможності фахівця в майбутньому необхідним $\epsilon$ формування його профресійної ідентичності $[12,19]$. Професійна підготовка майбутніх фахівців з фрізичної терапії та ерготерапії має бути спрямована насамперед на розвиток високого рівня базових професійних компетенцій, в основі якого лежить практичне навчання $[9,18,10]$. Навчальна практика має створювати сприятливі умови для взаємодії майбутніх фахівців з досвідченими фахівцями, що мають клінічний досвід в галузі фізичної терапії та ерготерапії [1;2].

Так, сучасні дослідження зауважують на необхідності включення у процес професійної підготовки фахівців досліджуваної галузі супервізії, як процесу професійної підтримки та навчання, яке дає можливість практикуючим особам розвивати знання та компетентність.

Питанням формування професійної ідентичності та підвищення конкурентоспроможності майбутніх фахівців з фізичної терапії та ерготерапії присвячено чимало робіт. Проте малодослідженим залишається питання впливу включення у процес професійної підготовки супервізії на якість професійної ідентичності майбутніх фізичних терапевтів та ерготерапевтів.

Інститут супервізії у сфрері фізичної терапії та ерготерапії в Україні сьогодні не $є$ достатньо включеним у процес професійної практичної підготовки майбутніх фахівців. Під практичною підготовкою розуміється будь-яка роль, в якій майбутній фахівець набуває навичок застосування свох вмінь та азнань як фізичного терапевта, ерготерапевта [7, 8, 14]. Практична підготовка не обмежується наданням прямої клінічної допомоги. Сюди також входить: робота прямому неклінічному зв'язку 3 пацієнтами/клієнтами; робота в управлінні, адміністрації, освіті, ауково-дослідницькій, консультативній, регуляторній ролі; будь-які інші ролі, які впливають на ефективне надання послуг за професією та/або використання професійних навичок $[11,13,22]$. Через це актуальним залишаеться дослідження значення та умов включення супервізії у процес професійної підготовки майбутніх фрахівців з фізичної терапії та ерготерапії.

Mета роботи: визначити теоретико-методологічні аспекти організації супервізії для формування профресійної ідентичності майбутніх фахівців з фізичної терапії та ерготерапії.

\section{II Матеріал і методи дослідження}

Нормативним підґрунтям встановлення цілей даного дослідження є такі нормативно-правові акти Міністерства охорони здоров'я та Міністерства освіти і науки України: 
- Довідник кваліфікаційних характеристик професій працівників. Випуск 78 «Охорона здоров'я», затверджений наказом Міністерства охорони здоров'я України від 29.03.2002 р. № 117 (зі змінами) [3];

- Стандарт вищої освіти України за спеціальністю 227 «Фізична терапія, ерготерапія» для першого (бакалаврського) рівня вищої освіти, затверджений наказом Міністерства освіти і науки України від 19.12.2018 р. № 1419 [6].

Методологічну основу при проведенні даного дослідження заклали такі підходи, як теоретичний аналіз науково-методичної літератури, синтез, узагальнення, порівняльний аналіз

Для вирішення мети дослідження був здійснений теоретичний аналіз педагогічної, медичної, філософської, психологічної та мультидисциплінарної літератури.

Результати дослідження були сформовані на основі проведеного аналізу, синтезу, порівняння, узагальнення, систематизації. 3 метою опису значення та структури організації супервізії у професійній підготовці фрахівців з фрізичної терапії та ерготерапії використано системно-структурний аналіз, для розробки та обгрунтуванні її компонентів - моделювання.

\section{III Результати}

Супервізія включає елементи направлення діяльності фахівця та настанови. Це формальний процес професійної підтримки та навчання, яке дає можливість практикуючим особам розвивати знання та компетентність, усвідомлювати відповідальність за власну практичну діяльність.

Супервізор - спеціально навчений фахівець з фізичної терапії/ерготерапії, який погодився на оцінку та моніторинг навчальної практичної діяльності майбутнього фрахівця з фізичної терапії та ерготерапії. Вимогою до супервізора $є$ наявність відповідної кваліфрікації та досвіду (як правило, не менше трьох років) професійної діяльності. Головне в діяльності супервізора - вміння організувати практичну діяльність як одного майбутнього фахівця з фізичної терапії, ерготерапії, так і команди, щоб кожен практик мав можливість максимально реалізувати власний потенціал у суспільній діяльності.

Майбутній фахівець з фрізичної терапії та ерготерапії під супервізією - це студент, який, для здобуття відповідного освітньо-каваліфікаційного рівня, проходить навчальну професійну практику 3 фізичної терапії та ерготерапії.

Супервізія пропонується автором, як унікальна творча технологія навчання майбутніх фрахівців 3 фрізичної терапії та ерготерапії, що базується та традиціях усної передачі знань. У зарубіжній практиці вона застосовується як в процесі практичного навчання студентів, так і в пооцесі самостійної роботи молодих фахівців, коли супервізор допомагає колезі набувати професійної мастерності. Довготривале (за кількістю лекційних, семінарських та практичних годин) навчання фізичній терапії та ерготерапії необхідно доповнювати процесом супервізії досвідченого керівника.

Функціями супервізора є:

1) навчальна;

2) інформаційна, коли супервізор передає майбутньому фахівцеві той чи інший обсяг знань, допомагає у виробленні стратегії фізичної терапії, ерготерапії;

3) підтримуюча в позитивних ресурсах для продовження свій діяльності;

4) оцінювальна, коли супервізор оцінює вибрані фізичним терапевтом, ерготерапевтом стратегії, методи та технології діяльності;

5) допомога в плануванні подальшої професійної діяльності.

Серед технологічних способів підтримки супервизором дієвої позиції майбутнього фахівця з фізичної терапії та ерготерапії під супервізією можна виділити:

- допомога в дотриманні меж діяльності (і супервізіі);

- допомога в пізнанні «сліпих плям» фізичного терапевта, ерготерапевта в поєднанні 3 демонстрацією розуміння і прийняття реального недосконалості навіть досвідченого фахівця;

- підтримка права власного бачення;

- відтворення супервизором власних професійних установок за допомогою особистих прикладів, технік саморозкриття.

Професійна ідентичність $є$ одним із показників рівня професійного становлення особистості, яка за своїм походженням $€$ придбаною та дозволяє усвідомити фрахівцю з фізичної терапії свою приналежність до своєї професії і належить до ії професійного співтовариства. 
Професійна ідентичність у своєму понятті тісно взаємопов'язана з такими поняттями, як професійний розвиток, професіоналізм, професійна самооцінка, професійне самовизначення, і є одним з основних критеріїв становлення професіонала в умовах конкурентного середовища. Іншими словами, сучасний професіонал, щоб існувати в динамічних соціально-економічних умовах, повинен бути здатний до постійного розвитку та аналізу, усвідомлення свого місця в професійному середовищі. Формування профеесійної ідентичності $€$ найважливішим завданням, яке постає перед фахівцем у період його професійного становлення.

Професійний вибір людини - це тривалий процес, що включає в себе ряд взаємопов'язаних рішень і стадій, розтягнутий більш ніж на десять років. При цьому процес вибору профресії $\epsilon$ незворотнім, що закінчується компромісом між зовнішніми і внутрішніми факторами. Під зовнішніми факторами ми розуміємо престиж професії, положення на ринку праці, під внутрішніми - індивідуальні психологічні особливості особистості.

Профресійна ідентичність - уявлення людини про своє місце в професійній групі, а також про місце своєї профресійної групи в системі суспільних відносин. Можна зробити висновок, що професійна ідентичність дозволяє орієнтуватися людині у світі професій, наділяючи людину ціннісними орієнтирами і забезпечуючи можливостями для самореалізації.

Описовий механізм структури професійної ідентичності може бути побудований через сукупність трьох основних компонентів: когнітивного, емоційно-оцінного та поведінкового. При цьому когнітивний компонент включає в себе професійні знання і професійні переконання, емоційно-оцінний - це емоційне ставлення до професійних переконань і знань, поведінковий компонент являє собою відповідну реакцію, яка, зокрема, може виражатися в поведінці.

Виділяють три основні лінії розвитку професійної ідентичності та, відповідно, три групи параметрів, які можна використовувати для оцінки рівня її сформованості. Кожна група відповідає структурному компоненту професійної ідентичності.

Перша група параметрів відповідає когнітивному компоненту профресійної ідентичності та характеризує ставлення людини до себе як майбутнього і діючого професіоналу, його реальну або прогнозовану професійну самооцінку. При цьому підході оцінюється різниця проектування реальної професійної Я-концепції особистості на ідеальну, а отриманий результат дозволяє оцінити рівень професійної самооцінки людини, знайти почуття професійної ідентичності та підставу для ії майбутнього розвитку.

Друга група параметрів представляє мотиваційний компонент професійної ідентичності та характеризує ставлення людини до змісту, умов професійної діяльності, іншими словами, показує задоволеність людини працею, а саме умовами та її змістом, рівнем її оплати, взаємовідносинами в колективі, можливостями професійного розвитку. При цьому підході професійна ідентичність формується шляхом проектування уявлення людиною свого ідеального мотиваційного потенціалу професійної ідентичності на уявлення людини про реальні можливості конкретної профресійної діяльності по задоволенню потреб і створення умов, що необхідні для самореалізації.

Третя група параметрів визначає оцінку ставлення людини до системи цінностей і норм, традицій, характерним для певної професійної групи і представляє ціннісний компонент профресійної ідентичності. Рівень сфрормованості професійної ідентичності в даному напрямі можливо оцінити в разі проекції власної системи професійних цінностей і позицій на уявлення про цінності і позиції, які, на думку людини, характерні для конкретної професійної групи.

Для того щоб визначити, як відбувається становлення професійної ідентичності, нами був проведений теоретичний аналіз наукових досліджень у даному напрямі.

Деякі автори розглядають професійну ідентичність як процес професійного розвитку людини, пов'язаний із професійним самовизначенням, професійною самооцінкою, професійною спрямованістю, яка включає в себе задоволеність професією і професійною діяльністю. Інші дослідники вважають, що професійна ідентичність - це властивість особистості, що виражається у взаємозв'язку когнітивних, мотиваційних і ціннісних особистісних характеристик.

Процес формування професійної ідентичності майбутніх фахівців із фрізичної терапії вимагає дотримання певних принципів. 
Шляхом онтологічного аналізу діалектичних законів і категорій нами визначено загальні методологічні принципи (засадничі ідеї, що формуються в процесі пізнання): об'єктивності, конкретності, історизму, науковості, діалектичності, детермінізму.

Формування професійної ідентичності зумовлюється поетапним розвитком людини.

Перший, допрофесійний етап, що проходить, на думку автора, в період дитинства людини, наповнений придбанням несистематичних, фррагментарних знань про різні професії. Далі, до кінця періоду шкільного дитинства, настає «передпрофесійний» етап, на якому в підлітка починає формуватися професійне самовизначення, що полягає в ототожненні себе з обраною професією і в одночасному відділенні від інших професій. У період професійного навчання настає усвідомлений етап, на якому майбутній фахівець починає розрізняти зміст різних професійних груп і може вже ідентифікувати себе з однією з них. Якщо профресійне самовизначення розвивається успішно, то процес формування професійної ідентичності може завершитися на цьому етапі. Четвертий етап, останній, характерний для періоду, коли вже завершилося навчання у вищому навчальному закладі, називається професійним етапом.

Перші три етапи формування професійної ідентичності відображають процес професійного самовизначення, тоді як четвертий етап характеризує формування професійної кар'єри.

Серед факторів, що роблять істотний вплив на формування професійної ідентичності, важливу роль відіграє освітнє середовище, підготовка майбутнього фахівця в системі вищої освіти.

Для формування професійної ідентичності на третьому етапі $€$ необхідним систематичне вдосконалення підготовки педагогів та інших працівників освітніх установ, переглядаючи традиційні підходи до змісту і методичних прийомів підготовки фахівців, здійснення формування соціально і професійно значущих ціннісних орієнтацій у системі навчально-виховної роботи вищих навчальних закладів, дотримання умов розвитку професійних та особистісних потреб студентів у самореалізації.

Шляхом вирішення цього завдання є включення супервізії у процес професійної підготовки фахівців з фізичної терапії та ерготерапії.

3 метою формування професійної ідентичності, у професійній підготовці майбутніх фахівців 3 фізичної терапії та ерготерапії велике значення має міжособистісна взаємодія супервізора і майбутнього фрахівця. За своїм значенням для професійного зростання фізичного терапевта, ерготерапевта супервізія займає другу позицію після безпосередньої практики, а супервізор - ключова фігура в професійному становленні фахівця. Саме супервізор регулює професійні дії фахівця в процесі його практичної діяльності, не даючи можливості закріпитися помилковим настановам.

Для досягнення ефективної супервізії важливо обрати ту технологію, яка найбільшою мірою відповідає особистісному стилю, області інтересів, світогляду, ступеня просресійної автономії, рівню зрілості як супервізора, так і студента. Майбутнім фахівцям необхідна повноцінна індивідуальна супервізія з наставником, здатним підтримати його професійний розвиток.

Корисною технологією для формування професійної ідентичності майбутніх фрахівців з фрізичної терапії та ерготерапії є фокусно-рольова матриця, що дозволяє детально проаналізувати складні випадки у професійній діяльності фізичних терапевтів та ерготерапевтів.

Супервізор може фокусуватися на різних аспектах діяльності фрізичного терапевта, ерготерапевта. Нижче виділено шість категорій, або варіантів, фокусу супервізії. Вони являють собою мовні відмітки, що характеризують рід активності в конкретний момент супервізії, завдяки яким вдається організувати навчальну практичну діяльність майбутніх фізичних терапевтів, ерготерапевтів.

1. Розповідь фахівця; історія пацієнта/клієнта. Фокус робиться на пацієнті/клієнті.

2. Дії фахівця: дослідження того, що він робив з клієнтом, - гіпотези, методи і техніки, інтервенції. Фокус на фахівця.

3. Процес консультування: дослідження взаємодії або «динаміки» в ході практичної діяльності фахівця. Фокус на діяльності в системі «фрізичний терапевт, ерготерапевт - пацієнт/клієнт». Система супервізії - взаємодія майбутнього фахівця з фізичної терапії та егротерапії з супервізором.

4. Стан фахівця з фрізичної терапії та ерготерапії під супервізією: цей фокус супервізії вже належить «другій стороні» процесу, де увага супервізора концентрується на стані фахівця з фізичної терапії та ерготерапії під супервізією під час супервізорської сесії, в тому числі на пережитих ним 
«блоках». Відбувається перехід від першої групи фокусів супервізії, пов'язаних з пацієнтом/клієнтом, до другої, де головні відносини - це відносини з супервизором.

5. Процес супервізії: дослідження відносин між супервизором і учнем, а також ймовірності паралельного процесу.

6. Враження супервізора: «підозри», висновки або ідеї супервізора, пов'язані з фрахівцем 3 фізичної терапії та ерготерапії під супервізією або пацієнтом/клієнтом, трансформуються в міркування на тему аспектів розповіді учня, що не знайшли вираження при фізіотерапевтичних або ерготерапевтичних втручаннях.

Як вчитель супервізор допомагає майбутньому фахівцю з фізичної терапії та ерготерапії оволодіти необхідними знаннями, інструктує, як використовувати вміння і навички, а також оцінює його професійну практичну діяльність. Як фасилітатор він полегшує вираз емоцій, підтримує перелічіні фокуси супервізії і процес комунікації. Будучи консультантом, він консультує учня в області його ускладнень, допомагає знайти ресурси. Як експерт супервізор виступає компетентним фахівцем в галузі фрізичної терапії та ерготерапії.

При організації супервізії важливим є принцип поступовості. У зв'язку з цим пропонується виділення чотирьох рівнів супервізії, які розроблені для безпечної навчальної практики майбутніх фахівців з фізичної терапії та ерготерапії (таблиця 1).

Табл. 1. Рівні супервізії у практичній підготовці фрахівців з фрізичної терапії та ерготерапії

\begin{tabular}{|c|c|c|}
\hline $\begin{array}{c}\text { Рівень } \\
\text { супервізії }\end{array}$ & Характеристика & Технічні умови \\
\hline 1 & $\begin{array}{l}\text { Супервізор бере пряму і } \\
\text { головну відповідальність } \\
\text { за окремих } \\
\text { пацієнтів/клієнтів }\end{array}$ & $\begin{array}{l}\text { Супервізор повинен бути фізично присутній на робочому місці, } \\
\text { коли майбутній фахівець з фізичної терапії та ерготерапії під } \\
\text { супервізією виконує практичну діяльність }\end{array}$ \\
\hline 2 & $\begin{array}{l}\text { Супервізор і майбутній } \\
\text { фахівець з фрізичної } \\
\text { терапії та } \\
\text { ерготерапії поділяють } \\
\text { відповідальність за } \\
\text { окремих } \\
\text { пацієнтів/клієнтів }\end{array}$ & $\begin{array}{l}\text { - Супервізор повинен бути фізично присутній на робочому місці } \\
\text { майбутнього фахівця з фізичної терапії під супервізією. } \\
\text { - Супервізія може бути доповнена телефонним контактом, але } \\
\text { не повиннен бути єдиною формою } \\
\text { супервізії. } \\
\text { - Майбутній фахівець з фізичної терапії та ерготерапії під } \\
\text { супервізією повинен } \\
\text { проконсультуватися з лікарем щодо ведення кожного } \\
\text { пацієнта/клієнта. }\end{array}$ \\
\hline 3 & $\begin{array}{l}\text { Майбутній фрахівець } 3 \\
\text { фізичної терапії та } \\
\text { ерготерапії під } \\
\text { супервізією приймає } \\
\text { основну } \\
\text { відповідальність за } \\
\text { практичну діяльність. }\end{array}$ & $\begin{array}{l}\text { - Супервізор повинен забезпечити наявність умов безпеки. } \\
\text { - Майбутньому фахівцю з фізичної терапії та ерготерапії під } \\
\text { супервізією дозволяється працювати } \\
\text { незалежно, за умови, що з супервізором легко } \\
\text { зв'язатисяпо телефону або іншим засобом зв'язку. } \\
\text { - Супервізор повинен регулярно переглядати } \\
\text { практику роботи майбутнього фахівця з фізичної терапії та } \\
\text { ерготерапії під супервізією. }\end{array}$ \\
\hline 4 & $\begin{array}{l}\text { Майбутній фрахівець з } \\
\text { фізичної терапії та } \\
\text { ерготерапії під } \\
\text { супервізією приймає } \\
\text { повну } \\
\text { відповідальність за } \\
\text { практику. }\end{array}$ & $\begin{array}{l}\text { - Супервізор повинен забезпечити широкий нагляд за } \\
\text { практикою. } \\
\text { - Супервізор повинен бути доступний для розгляду } \\
\text { справи або консультації, якщо цього потребує майбутній } \\
\text { фахівець з фізичної терапії та ерготерапії під супервізією. } \\
\text { - Супервізор повинен проводити відповідні огляди } \\
\text { практики майбутнього фахівця з фізичної терапії та ерготерапії } \\
\text { під супервізією. }\end{array}$ \\
\hline
\end{tabular}


Для досягнення позитивних результатів супервізії, зокрема якісного формування професійної ідентичності студента, як супервізор, так і майбутній фрахівець з фізичної терапії та ерготерапії під супервізією, мають виконувати певні обов'язки, що наведені нижче.

Обов'язки супервізора:

1. Дотримання умов безпечної практики майбутнього фахівця з фізичної терапії та ерготерапії під супервізією.

2. Забезпечення чіткої супервізії та конструктивного зворотного зв'язку та розуміння, як може супервізор зв'язатися з майбутнім фрахівцем з фрізичної терапії та ерготерапії під супервізією.

3. Контроль того, що фахівець (майбутній) з фізичної терапії та ерготерапії під супервізією здійснює практику відповідно до контролю плану практики та схеми роботи.

4. Переконання в тому, що фрахівець (майбутній) з фізичної терапії та ерготерапії під супервізією розуміє свої юридичні обов'язки та положення обмеження, в межах яких він повинен діяти; дотримується етичних принципів, що застосовуються у професії; діє відповідно до вказівок супервізора.

5. Розуміння значення супервізії як початку профресійної діяльності та взяти на себе цю роль включаючи регулярний, захищений, запланований час з фрахівцем (майбутнім) з фізичної терапії та ерготерапії під супервізією.

6. Висвітлення керівництву установи, де проходить практика, будь-яких конфліктів інтересів 3 фахівцем (майбутнім) з фізичної терапії та ерготерапії під супервізією.

7. Надання вчасних і точних звітів про перебіг практики.

Обов'язки майбутнього фахівця з фізичної терапії та ерготерапії під супервізією:

1. На початку спільно з супервізором встановити навчальні потреби.

2. Брати на себе відповідальність за дотримання розкладу регулярних зустрічей з супервізором.

3. Бути належним чином підготовленим до зустрічей з супервізором.

4. Брати участь в оцінюванні, що проводиться супервізором для визначення рівня супервізії, подальшої потреби у супервізії.

5. Визнавати межі своєї профресійної компетентності.

6. Повідомляти супервізор про потребу настанов щодо навчальної практики та брати на себе відповідальність за їх дотримання.

7. Ознайомитись та дотримуватись нормативних, професійних та юридичних обов'язків стосовно практики.

8. Своєчасно повідомляти супервізора про будь-які клінічні випадки у період супервізії, які можуть мати негативні наслідки.

9. Ознайомлення з відгуками та відповідь на них.

Виконання власних обов'язків супервізором та майбутнім фахівцем з фізичної терапії та ерготерапії під супервізією $€$ необхідною умовою її проведення. Виконуючи власні обов'язки, студент усвідомлює своє місце у професійній сфері, що в подальшому відобразиться на виконання ним професійної діяльності. Так майбутній фахівець з фізичної терапії та ерготерапії може сформувати три основні компоненти професійної ідентичності: когнітивний, емоційно-оцінний та поведінковий. При цьому когнітивний компонент включає в себе професійні знання і професійні переконання, емоційнооцінний - це емоційне ставлення до професійних переконань і знань, поведінковий компонент являє собою відповідну реакцію, яка, зокрема, може виражатися в поведінці.

\section{IV Обговорення}

Питання формування професійної ідентичності майбутніх фахівців з фізичної терапії та ерготерапії $є$ актуальним серед досліджень сучасних науковців, зокрема R. Hammond, V. Cross, A. Moore, K. Hossein, O. Carole, L. Heather, F. Randa. Результати аналізу досліджень перелічених вчених свідчать про те, що у процесі професійного становлення майбутніх фахівців важливе значення має рольове навчання, що включає норми, цінності, якості, необхідні для становлення студента, як фрізичного терапевта/ерготерапевта $[15,17]$ Особлива увага у проведених дослідженнях приділяється організації клінічної практики під керівництвом досвідченого, спеціально підготовленого кваліфікованого фізичного терапевта/ерготерапевта. Це і дозволяє стверджувати, що включення супервізії у процес 
професійної підготовки майбутніх фахівців з фізичної терапії та ерготерапії необхідне для формування професійної ідентичності даних фахівців.

Теоретичний аналіз різних концепцій і підходів до вивчення даного поняття дозволяє визначити поняття «ідентичність» як багатовимірний і інтегративний психологічний феномен, що представляє собою результат активного процесу уявлення особистості про себе, пов'язаного з безперервним процесом розвитку особистості людини протягом усього його життя [19]. Одночасно слід зазначити, що даний процес не є лінійним процесом і може мати зворотний ефект, повертаючись на більш низький рівень. При цьому людина робить серію взаємопов'язаних виборів, приймаючи свої особисті цілі, цінності, переконання [22, 24, 25].

Доцільно розглядати професійну ідентичність не лише як усвідомлення своєї тотожності 3 профресійною спільнотою, а й її оцінку, психологічну доцільність членства в ній, що розділяються на профресійні почуття, своєрідну ментальність, відчуття своєї професійної компетентності, самостійності й самоефективності, тобто переживання своєї професійної цілісності та визначеності [5].

Результати проведеного дослідження з особливостей організації супервізії у процесі профресійної підготовки фахівців з фрізичної терапії збігаються з дослідженнями таких вчених, як Korpi H., Piirainen A., Peltokallio L. та інших, вказуючи на те, що професійна ідентичність у фізіотерапії та ерготерапії складніша, ніж традиційно вважається. Для її якісного фрормування необхідним є якісно з педагогічної точки зору та професійно, з боку фізіотерапії та ерготерапії організована супервізія під час проведення навчальної практики.

У зарубіжних моделях підготовки фрахівців з фрізичної терапії та ерготерапії супервізор несе віповідальність за те, щоб фахівець, який ще не отримав відповідну кваліфікацію, міг якісно рганізувати свою професійну діяльність [11, 16]. Має сенс продовжувати супервізію декілька років. У процесі супервізії супервізор покликаний підтримувати професійну позицію майбутнього фахівця [14]. Це означає надання допомоги фахівцю в розкритті чи стримуванні власних почуттів (як прийнятних, так і заперечуваних - страх, розгубленість, гнів) в залежності від необхідності; фокусування на проблемах пацієнта/клієнта без підміни їх власними; усвідомлення як своїх можливостей, так і зон ризику; гнучкість у виборі і використанні засобів впливу на пацієнта/клієнта та інше.

Студенти, що проходять навчальну практику під керівництвом супервізора, протягом супервізії руйнують бар'єри професійної взаємодії як з фізіотерапевтами та ерготерапевтами, так і з фахівцями суміжних областей $[7,8,21]$. Проведення консультацій з супервізором, як з наставником та колегою, викликає у майбутнього фахівця ключове почуття для формування професійної ідентичності. Це почуття включення у професійний простір дозволяє створити у майбутніх фрахівців свій власний погляд на професійну діяльність у сферах фрізичної терапії та ерготерапії, як на більш широкий спектр можливостей професійної діяльності.

\section{V Висновки}

Результати проведеного дослідження дозволили визначити теоретико-методологічні аспекти організації супервізії для формування професійної ідентичності майбутніх фахівців з фізичної терапії та ерготерапії.

Супервізію слід розглядати, як формальний процес професійної підтримки та навчання, який дає можливість практикуючим особам розвивати знання та компетентність, усвідомлювати відповідальність за власну практичну діяльність.

Встановлено, що професійна ідентичність у своєму понятті тісно взаємопов'язана з такими поняттями, як професійний розвиток, професіоналізм, професійна самооцінка, професійне самовизначення, і $є$ одним з основних критеріїв становлення професіонала в умовах конкурентного середовища. Формування просресійної ідентичності $є$ найважливішим завданням, яке постає перед фахівцем у період його професійного становлення.

На основі цього виділені технологічні способи підтримки супервізором дієвої позиції майбутнього фахівця з фізичної терапії та ерготерапії під супервізією. Для досягнення ефективної супервізії для формування профресійної ідентичності майбутніх фрахівців з фрізичної терапії та ерготерапії корисною технологією $є$ фокусно-рольова матриця, що дозволяє детально проаналізувати складні випадки у профресійній діяльності фізичних терапевтів та ерготерапевтів. 
При організації супервізії важливим є принцип поступовості. У зв'язку з цим пропонується виділення чотирьох рівнів супервізії, які розроблені для безпечної навчальної практики фахівців 3 фрізичної терапії та ерготерапії.

Результати дослідження дозволили виділити обов'язки як супервізора, так і майбутнього фахівця з фізичної терапії та ерготерапії, що перебуває під супервізією, виконання яких необхідне для досягнення позитивних результатів супервізії. Результати проведеного аналізу науково-методичної літератури дозволили визначити, що виконання виділених обов'язків суб'єктами навчальної практики дозволить майбутньому фахівцю з фізичної терапії та ерготерапії сформувати три основні компоненти професійної ідентичності: когнітивний, емоційно-оцінний та поведінковий.

Перспективами подальших досліджень $є$ питання, пов'язані із включенням супервізії у процес професійної підготовки фахівців з фрізичної терапії та ерготерапії.

\section{Бібліографрічні посилання}

1. Дмітрієва Н. С., Копочинська Ю. В. Наукове обгрунтування застосування інтегративного підходу у підготовці фахівців 3 фізичної терапії. Молодий вчений. 2018. № 12. С. 420-424. doi: https://doi.org/10.32839/2304-5809/2018-12-64-96.

2. Дмітрієва Н. С., Копочинська Ю. В. Формування професійної ідентичності майбутніх фрахівців з фрізичної терапії як фактор підвищення їх конкурентоспроможності. Збірник наукових праць [Херсонського державного університету]. Педагогічні науки. 2019. Вип. 79(3). С. 105-110. doi: 10.32999/ksu2413-1865/2019-87-19

3. Довідник кваліфікаційних характеристик професій працівників. Випуск 78 «Охорона здоров'я», затверджений наказом Міністерства охорони здоров'я України 29.03.2002 $\quad$ p. № 117 (зі змінами). URL: http://zakon.rada.gov.ua/rada/show/va117282-02 (дата звернення: 09.10.2019).

4. Копочинська Ю. В. Деякі загальнонаукові підходи до формування професійної ідентичності майбутніх фахівців із фізичної реабілітації. Збірник наукових праць [Херсонського державного університету]. Педагогічні науки. 2017. Вип. 79(3). C. 153-159. URL: http://nbuv.gov.ua/UJRN/znppn_2017_79(3)_31.

5. Копочинська Ю. В., Дмітрієва Н. С. Базові компетенції майбутніх фахівців з фізичної терапії та ерготерапії у становленні професійної майстерності. Науковий часопис Національного педагогічного університету імені М.П. Драгоманова. Серія № 15. Науково-педагогічні проблеми фрізичної культури (фрізична культура і спорт): збірник наукових праць. 2019. Вип. 4 (112). С. 51 - 57.

6. Стандарт вищої освіти за спеціальністю 227 «Фізична терапія, ерготерапія» для першого (бакалаврського) рівня освіти, затверджений наказом Міністерства освіти і науки України від 19.12.2018 p. URL: https://osvita.ua/doc/files/news/630/63031/227-fizichna-terapiya-ergoterapiya-bakal.pdf (дата звернення: 09.10.2019).

7. Aguilar-Rodríguez M., Marques-Sule E., Serra-Añó P., Dueñas L., Sempere-rubio N. Elaboración y validación del «Cuestionario de actitudes hacia la ética profesional en Fisioterapia». Fisioterapia. 2017. Vol. 39. doi: 10.1016/j.ft.2016.12.001.

8. Aguilar-Rodríguez M., Marques-Sule E., Serra-Añó P., Espí-López G. V., Dueñas-Moscardó L., Pérez-Alenda S. A blendedlearning programme regarding professional ethics in physiotherapy students. Nursing Ethics. 2019. Vol. 26(5), P. 1410-1423. https://doi.org/10.1177/0969733017748479

9. Atkinson R., McElroy T. Preparedness for physiotherapy in private practice: Novices identify key factors in an interpretive description study. Manual Therapy. 2016. Vol. 22, P. 116-121. doi:10.1016/j.math.2015.10.016

10. Becker M., Dudley-Javoroski S. Shields, Richard K. Professionalism Values in Health Science Education: Self- and PeerAssessment of Faculty, Staff, and Students. Journal of Allied Health. 2017. Vol. 46, No 3. P. 178-184.

11. Black L. L., Jensen G. M., Mostrom E., Perkins J., Ritzline P. D., Hayward L., Blackmer B. The First Year of Practice: An Investigation of the Professional Learning and Development of Promising Novice Physical Therapists. Physical Therapy. 2010. Vol. 90. P. 1758-1773. https://doi.org/10.2522/ptj.20100078

12. Clarkson H. J., Thomson O. P. 'Sometimes I don't feel like an osteopath at all'- a qualitative study of final year osteopathy students' professional identities. International Journal of Osteopathic Medicine. 2017. Vol. 26. P. $18-27$. https://doi.org/10.1016/j.ijosm.2017.09.001. (http://www.sciencedirect.com/science/article/pii/S1746068917300986)

13. Guidelines for Supervision, Roles, and Responsibilities During the Delivery of Occupational Therapy Services. American Journal of Occupational Therapy, November/December 2009, Vol. 63, pp. 797-803. doi: 10.5014/ajot.63.6.797

14. Hall T., Cox D. Clinical supervision: an appropriate term for physiotherapists?. Learning in Health and Social Care. 2009 , Vol. 8. P. 282 - 291. doi: 10.1111/j.1473-6861.2009.00226.x.

15. Hammond R., Cross V., Moore A. The construction of professional identity by physiotherapists: A qualitative study. Physiotherapy. 2016. Vol. 102, P. 71-77. doi:10.1016/j.physio.2015.04.002

16. Harman K., Sim M., LeBrun J., Almost J., Andrews C., Davies H., Khalili H., Sutton E., Price S. Physiotherapy: an active, transformational, and authentic career choice. Physiotherapy Theory and Practice. 2019. P. 1-14. doi: 10.1080/09593985.2019.1639230.

17. Inman J., Thomson O. P., 'Complementing or conflicting? A qualitative study of osteopaths' perceptions of NICE low back pain and sciatica guidelines in the UK. International Journal of Osteopathic Medicine. 2019. Vol. 31. P. 7-14. 
18. Khalili H., Hall J., Deluca S. Historical analysis of professionalism in western societies: Implications for interprofessional education and collaborative practice. Journal of interprofessional care. 2014. Vol. 28. doi: 10.3109/13561820.2013.869197.

19. Khalili H., Orchard C., Laschinger H., Randa F. An interprofessional socialization framework for developing an interprofessional identity among health professions students. Journal of interprofessional care. 2013. Vol. 27. doi: 10.3109/13561820.2013.804042.

20. Korpi H., Piirainen A., Peltokallio L., Practical work in physiotherapy students' professional development. Reflective Practice. 2017. P. 821 - 836. doi: 10.1080/14623943.2017.1361920

21. Lee S., Denniston C., Edouard V., Palermo C., Pope K., Sutton K., Waller S.,Ward B., Rees C. Supervision training interventions in the health and human services: realist synthesis protocol. British Medical Journal. 2019. Open. 9. e025777. doi: 10.1136/bmjopen-2018-025777.

22. Paskaleva R. Effect of innovations in kinesitherapy and ergotherapy training on the students' motivation for practical work. British Medical Bulletin. 2016. P. 321-333.

23. Supervision guidelines for physiotherapy. URL: https://www.physiotherapyboard.gov.au/Codes-Guidelines/Supervisionguidelines.aspx (accessed 02.10.2019).

24. Tynjälä, P., Häkkinen, P., \& Hämäläinen, R. TEL@work: Toward integration of theory and practice. British Journal of Educational Technology. 2014. Vol. 45. P. 990-1000. doi:10.1111/bjet.12164

25. Tynjälä, P., Virtanen, A., Klemola, U., Kostiainen, E., \& Rasku-Puttonen, H. Developing social competence and other generic skills in teacher education: Applying the model of integrative pedagogy. European Journal of Teacher Education. 2016. Vol.39. P. 368-387. doi:10.1080/02619768.2016.1171314

\section{References}

1. Dmitriieva N. S., Kopochynska Yu. V. (2018). Naukove obhruntuvannia zastosuvannia intehratyvnoho pidkhodu u pidhotovtsi fakhivtsiv z fizychnoi terapii [Scientific substantiation of application of integrative approach in training of specialists in physical therapy]. Molodyi vchenyi [Young scientist], 12, 420-424. doi: https://doi.org/10.32839/2304-5809/2018-12-64-96.

2. Dmitriieva N. S., Kopochynska Yu. V. (2019). Formuvannia profesiinoi identychnosti maibutnikh fakhivtsiv z fizychnoi terapii yak faktor pidvyshchennia yikh konkurentospromozhnosti [Formation of the Professional Identity of Future Physical Therapy Specialists as a Factor for Increasing their Competitiveness]. Zbirnyk naukovykh prats [Khersonskoho derzhavnoho universytetu]. Pedahohichni nauky [Collection of Scientific Papers [Kherson State University]. Pedagogical Sciences], 79(3), 105-110. doi: 10.32999/ksu2413-1865/2019-87-19

3. Dovidnyk kvalifikatsiinykh kharakterystyk profesii pratsivnykiv. Vypusk 78 «Okhorona zdorov'ia», zatverdzhenyi nakazom Ministerstva okhorony zdorov'ia Ukrainy 29.03.2002 r. № 117 (zi zminamy) [Handbook of qualification characteristics of professions of workers. Issue 78 "Health" approved by the order of the Ministry of Health of Ukraine on March 29, 2002 No. 117 (as amended)] Retrieved from http://zakon.rada.gov.ua/rada/show/va117282-02 (accessed 09.10.2019).

4. Kopochynska Yu. V. (2017). Deiaki zahalnonaukovi pidkhody do formuvannia profesiinoi identychnosti maibutnikh fakhivtsiv iz fizychnoi reabilitatsii [Some general scientific approaches to the formation of professional identity of future specialists in physical rehabilitation]. Zbirnyk naukovykh prats [Khersonskoho derzhavnoho universytetu]. Pedahohichni nauky [Collection of Scientific Papers [Kherson State University]. Pedagogical Sciences], 79(3), 153-159. Retrieved from http://nbuv.gov.ua/UJRN/znppn_2017_79(3)_31.

5. Kopochynska Yu. V., Dmitriieva N. S. (2019). Bazovi kompetentsii maibutnikh fakhivtsiv z fizychnoi terapii ta erhoterapii u stanovlenni profesiinoi maisternosti [Basic competences of future specialists in physical therapy and ergotherapy in the development of professional skill]. Naukovyi chasopys Natsionalnoho pedahohichnoho universytetu imeni M.P. Drahomanova. Seriia № 15. Naukovo-pedahohichni problemy fizychnoi kultury (fizychna kultura i sport): zbirnyk naukovykh prats [Scientific journal of the National Pedagogical University named after M.P. Drahomanov. Series № 15. Scientific and pedagogical problems of physical culture (physical culture and sports): Collection. scientific works], 4 (112), 51 - 57.

6. Standart vyshchoi osvity za spetsialnistiu 227 «Fizychna terapiia, erhoterapiia» dlia pershoho (bakalavrskoho) rivnia osvity, zatverdzhenyi nakazom Ministerstva osvity i nauky Ukrainy vid 19.12.2018 r. [Higher education standard in the specialty 227 "Physical therapy, ergotherapy" for the first (bachelor) level of education, approved by the order of the Ministry of Education and Science of Ukraine from 19.12.2018] Retrieved from https://osvita.ua/doc/files/news/630/63031/227-fizichna-terapiyaergoterapiya-bakal.pdf (accessed 09.10.2019).

7. Aguilar-Rodríguez M., Marques-Sule E., Serra-Añó P., Dueñas L., Sempere-rubio N. (2017). Elaboración y validación del "Cuestionario de actitudes hacia la ética profesional en Fisioterapia». Fisioterapia, 39, doi: 10.1016/j.ft.2016.12.001.

8. Aguilar-Rodríguez M., Marques-Sule E., Serra-Añó P., Espí-López G. V., Dueñas-Moscardó L., Pérez-Alenda S. (2019). A blended-learning programme regarding professional ethics in physiotherapy students. Nursing Ethics, 26(5), $1410-1423$. https://doi.org/10.1177/0969733017748479

9. Atkinson R., McElroy T. (2016). Preparedness for physiotherapy in private practice: Novices identify key factors in an interpretive description study. Manual Therapy, 22, 116-121, doi:10.1016/j.math.2015.10.016

10. Becker M., Dudley-Javoroski S. Shields, Richard K. (2017). Professionalism Values in Health Science Education: Self- and Peer-Assessment of Faculty, Staff, and Students. Journal of Allied Health, 46, 3,178-184.

11. Black L. L., Jensen G. M., Mostrom E., Perkins J., Ritzline P. D., Hayward L., Blackmer B. (2010). The First Year of Practice: An Investigation of the Professional Learning and Development of Promising Novice Physical Therapists. Physical Therapy, 90, 1758-1773, https://doi.org/10.2522/ptj.20100078 
12. Clarkson H. J., Thomson O. P. (2017). 'Sometimes I don't feel like an osteopath at all'- a qualitative study of final year osteopathy students' professional identities. International Journal of Osteopathic Medicine, 26, 18-27, https://doi.org/10.1016/j.josm.2017.09.001. (http://www.sciencedirect.com/science/article/pii/S1746068917300986)

13. Guidelines for Supervision, Roles, and Responsibilities During the Delivery of Occupational Therapy Services. American Journal of Occupational Therapy, November/December 2009, 63, 797-803. doi: 10.5014/ajot.63.6.797

14. Hall T., Cox D. (2009). Clinical supervision: an appropriate term for physiotherapists?. Learning in Health and Social Care, 8 , 282 - 291. doi: 10.1111/j.1473-6861.2009.00226.x.

15. Hammond R., Cross V., Moore A. (2016). The construction of professional identity by physiotherapists: A qualitative study. Physiotherapy, 102, 71-77, doi:10.1016/j.physio.2015.04.002

16. Harman K., Sim M., LeBrun J., Almost J., Andrews C., Davies H., Khalili H., Sutton E., Price S. (2019). Physiotherapy: an active, transformational, and authentic career choice. Physiotherapy Theory and Practice, 1-14. doi: 10.1080/09593985.2019.1639230.

17. Inman J., Thomson O. P. (2019). 'Complementing or conflicting? A qualitative study of osteopaths' perceptions of NICE low back pain and sciatica guidelines in the UK. International Journal of Osteopathic Medicine, 31, 7-14.

18. Khalili H., Hall J., Deluca S. (2014). Historical analysis of professionalism in western societies: Implications for interprofessional education and collaborative practice. Journal of interprofessional care, 28, doi: 10.3109/13561820.2013.869197.

19. Khaliil H., Orchard C., Laschinger H., Randa F. (2013). An interprofessional socialization framework for developing an interprofessional identity among health professions students. Journal of interprofessional care, 27, doi: 10.3109/13561820.2013.804042.

20. Korpi H., Piirainen A., Peltokallio L., (2017). Practical work in physiotherapy students' professional development. Reflective Practice, 821 - 836, doi: 10.1080/14623943.2017.1361920

21. Lee S., Denniston C., Edouard V., Palermo C., Pope K., Sutton K., Waller S.,Ward B., Rees C. (2019). Supervision training interventions in the health and human services: realist synthesis protocol. British Medical Journal, Open. 9. e025777. doi: 10.1136/bmjopen-2018-025777.

22. Paskaleva R. (2016). Effect of innovations in kinesitherapy and ergotherapy training on the students' motivation for practical work. British Medical Bulletin, 321-333.

23. Supervision guidelines for physiotherapy. Retrieved from https://www.physiotherapyboard.gov.au/CodesGuidelines/Supervision-guidelines.aspx (accessed 02.10.2019).

24. Tynjälä P., Häkkinen P., Hämäläinen R. (2014). TEL@work: Toward integration of theory and practice. British Journal of Educational Technology, 45, 990-1000. doi:10.1111/bjet.12164

25. Tynjälä P., Virtanen A., Klemola U., Kostiainen E., Rasku-Puttonen H. (2016). Developing social competence and other generic skills in teacher education: Applying the model of integrative pedagogy. European Journal of Teacher Education, 39, 368-387. doi:10.1080/02619768.2016.1171314

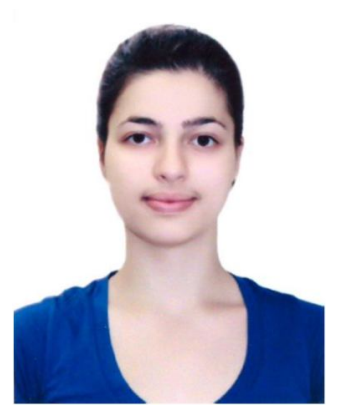

Дмітрієва Ніколь Субханівна,

студент,

Міжнародний науково-технічний університет імені академіка Юрія Бугая, провулок Магнітогорський, 3, м. Київ, Україна, 02000.

Tel. +38(067)765-61-99. E-mail: nikolestern@ukr.net.

\section{Dmitriieva Nikol Subkhanivna,}

Student,

Akademician Youriy Bugay International Scientific and Technical University,

Lane Magnitogorsk, 3, Kyiv, Ukraine, 02000

Tel. +38(067)765-61-99. E-mail: nikolestern@ukr.net.

ORCID: 0000-0001-6492-3371

\section{Citation (APA):}

Dmitriieva, N. (2019). Theoretical and methodological aspects of the organization of supervision for the formation of professional identity of future specialists in physical therapy, ergotherapy. Engineering and Educational Technologies, 7 (4), 45-56. doi: https://doi.org/10.30929/2307-9770.2019.07.04.04

\section{Цитування (ДСТУ 8302:2015):}

Дмітрієва Н. С. Теоретико-методологічні аспекти організації супервізії для формування профресійної ідентичності майбутніх фахівців з фозичної терапії, ерготерапії / Інженерні та освітні технології. 2019. Т. 7. № 4. С. 45-56. doi: https://doi.org/10.30929/2307-9770.2019.07.04.04

Обсяг статmі: сторінок-12; умовних друк. аркушів - 1,738. 